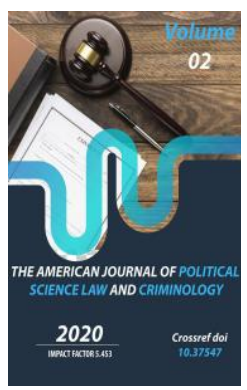

\title{
Peculiarities Of Forming Professional Ethics Of Judges In The Republic Of Uzbekistan
}

Copyright: Original content from this work may be used under the terms of the creative commons attributes 4.0 licence.

\section{Nurali Kurbonov}

Assistant Prof. PhD, The Supreme Court Of The Republic Of Uzbekistan On Board Supreme School Of Judges Head Of The Department Of "Professional Skills", Uzbekistan

\section{ABSTRACT}

The article illustrates scientific disciplines and analytical views on the specifics of the development of professional ethics of judges, a new model of compliance with the principles of ethics of judges, the specifics of the independence of judges.

\section{KEYWORDS}

Justice, professional ethics, ethics, honor of a judge, judicial power, honor, dignity, independence, impartiality.

\section{INTRODUCTION}

The Constitution provides for the independence of judges who are subject only to the law. Any interference with the activities of judges in the administration of justice is prohibited and such interference is punishable by law. The independence and immunity of judges is guaranteed by law. President Shavkat Mirziyoyev, drawing attention to this issue, said that the court should not be allowed to become a body in the hands of any official. Therefore, it was emphasized that the responsibility will be increased against interfering in court proceedings or putting pressure on the court. It should be noted that one of the main reasons why judges are guaranteed independence at the constitutional level and only in accordance 
with the law is that they have the right to administer justice only by the courts.

The Law of the Republic of Uzbekistan "On Courts" states that judges must strictly adhere to the rules of ethics for judges, refrain from actions that may damage the reputation of the judiciary, the dignity of judges, or call into question the impartiality of judges.

The Code of Ethics of Judges of the Republic of Uzbekistan states that a judge must adhere to the highest standards of etiquette and morality, unconditionally adhere to the norms of this Code, be fair in any situation, undermine the authority of the judiciary and does not damage its reputation. A judge must adhere to his oath, observance of this Code must be the order of the judge's heart, the rule of his life, strengthening public confidence in the judiciary, administering justice in a competent, be independent, impartial and fair manner, should always remember the qualities of intelligence, politeness, honesty, perseverance, thirst for knowledge, in order to be worthy of a high judicial status in society, always remember that a judge has no right to exercise judicial powers without a high moral and qualification level [1].

In carrying out his duties, a judge must always feel and act that he is a professional, that he can fulfill his duties only in accordance with the requirements of the law and that he must make a fair decision, deeply aware of the prestige and responsibility of the judiciary.

On June 30, 2020, President Mirziyoyev also spoke at a videoconference dedicated to the tasks of ensuring justice and combating corruption, noting that "everyone who comes to the courthouse must believe that there is justice in Uzbekistan".
The lawyer M. Rajabova stated that a real judge should be able to make a fair decision in any case. Only then he will be able to justify the enormous responsibility that lying on his shoulders. Honesty of the judge is the basis of justice in society» [2]

Absolute compliance by judges with the Code of Ethics is an important condition of their right to exercise judicial power and their compatibility with the status of judges for the concept of morality,

"Morality" is an Arabic word meaning behavior, upbringing, etiquette arising from the objective relations between a person and society, which regulates life and activities of each person on the basis of harmonizing personal and common interests. certain manners, manners, represents the notion that behavior is a set of norms.

Regardless of the profession in society, there is a professional ethics that embodies certain rules of conduct and behavior associated with this profession. A natural question arises: what is professional ethics? Professional ethics is the study and application of ethical norms, principles and qualities inherent in each profession. There is no absolute, eternal and unchanging morality in society. Morality is a social phenomenon that changes historically and has relative independence. In addition to this concept, there is the concept of professional ethics, which is a set of actions, such as a clear professional duty, honor, dignity, dignity, in which the rules of ethics adopted by society in relation to the specialties of people are applied, peculiar appearance. The concepts above have been manifested as a definite, integral part of a particular profession. This etiquette did not create by a single person. These concepts have been 
passed down from generation to generation and formed during long periods.

A Code of Conduct was established for judges in their professional activities and outside working hours. Restrictions on the work of the court outside the office, participation in economic activities, interaction with the media, issues of interaction with the state, citizens' self-government bodies and other public actions of organizations.

But, unfortunately, there have been recent incidents that have negatively affected on the reputation of some judges.

In particularly, gross violation of the rules of professional ethics leads to justified complaints of citizens against the judicial system and judges.

The judicial community, including the Supreme Court of the Republic of Uzbekistan, the Supreme Council of the Republic of Uzbekistan and the High School of Judges under the Supreme Council of the Republic of Uzbekistan, is taking a number of measures to improve the morale of judges..

Many reforms have been implemented in order to improve the quality of justice, strengthen guarantees for the protection of the rights, freedoms and legitimate interests of individuals and legal entities, as well as the Action Strategy in five priority areas of development of the Republic of Uzbekistan for 2017-2021years

As a result of the reforms, the long-term practice of considering cases in courts was completely abolished, the Supreme Council of Judges of the Republic of Uzbekistan was created, one of the main directions of its activity was to ensure the independence of judges.

In addition to all reforms, it was established the Higher School of Judges under the Council, and new methods of teaching judges were introduced at the school.

The School of Judges is aimed at training honest, non-corrupt judges and court staff in professional ethics, as well as increasing their theoretical knowledge and practical skills to form a fair judicial system.

Currently, courses are being held in professional ethics, management skills, forensic psychology, business communication and time management skills, as well as foreign languages, negotiation tactics, information technology, interpretation and application of legal norms to enhance the professional skills of judges and judicial candidates.

For this, qualified scientists and practitioners are hired in the School of Judges.

A judge must remember that the protection of human rights and freedoms by the judiciary in the administration of justice is the main goal of the judiciary.

A judge must maintain honor and dignity, adhere to moral standards, be modest, kind.

A judge should not take any action in the performance of his or her duties that might compromise the independence and impartiality of a judge, or allow others act as well.

There is no any exaggeration if we say that the adoption of the new version of the Code of Judicial Ethics in the judicial system of Uzbekistan has become an important factor in protecting the independence, impartiality and 
impartiality of the judiciary, as well as the rights and freedoms of citizens. The Code of Ethics for Judges is based on the Constitution of the Republic of Uzbekistan, the Laws of the Republic of Uzbekistan "On Courts", the Law of the Republic of Uzbekistan "On the High Council of Judges", the generally recognized principles of international law governing the ethics of judges and society. The Code of Judicial Ethics also embodies the principles of independence, impartiality, honesty and purity, respect for ethnic norms, equality, competence and aspirations, which are the Bangalore principles of judicial ethics, adopted on November 26, 2002 in The Hague. Ethical principles of judges in Uzbekistan have been formed for centuries, and a number of scholars have different approaches on this issue since the creation of the Judicial Institute in Central Asia. For example, Burhanuddin al-Margilani's "al-Khidaya" has a separate chapter, "Kitab adab al-Qazi". It describes the people who deserve to be judges, their conditions, the manner of the judge, his behavior during sentencing and the conditions in which he interacts with people in society

Also among the individual books on judicial etiquette is the book of Imam Mawardi "Odob al-Qazi". This book describes how flawlessly the judicial system has functioned in Islam since ancient times.

"A judge must always work on himself, expand his knowledge, be firm, persistent, not strive for personal gain in any matter, be attentive, calm, honest, polite and free from rudeness, cruelty, deception, hypocrisy. He must also make fair decision". [3]

Indeed, rules that have evolved over the centuries as a result of the demands on the courts now impose a number of rights and obligations on judges.

Judges are guided by ethical principles in their professional activities, and judges are obliged to adhere to these principles in their work.

This includes the principles of independence of judges, impartiality and impartiality of judges, equality, fairness of judges, honesty of judges and competence of judges.

The principles of independence of judges and their impartiality are among the basic principles that a judge must follow from the moment of taking the oath.

In practice, ensuring the independence and impartiality of judges is one of the main conditions for the development of the state and society, as well as the fact that judges make fair decisions and ensure the consent of citizens from the state.

It is necessary to identify and eliminate factors hindering the independence of judges, to educate citizens in the spirit of respect for judges. In the end, we will not be able to achieve our goal if we do not convince the judges to make fair decisions.

In conclusion, we must select honest and conscientious judges committed to their profession in order to make fair decisions in society, and pay special attention to education and training so that they can reach professional maturity.

For this, a judge must constantly work on himself, delve into the essence of the case in his proceedings and make a fair decision. At the same time, a judge should not succumb to such vices as arrogance and pride, and should be humble, humble and civilized in life. If a judge possesses these qualities and always adheres 
The American Journal of Political Science Law and Criminology (ISSN - 2693-0803)

Published: December 31, 2020 | Pages: 139-143

Doi: https://doi.org/10.37547/tajpslc/Volume02Issue12-21

to them, this will increase the prestige of the

judge, the authority of the judiciary.

\section{REFERENCES}

1. The Code of Ethics for Judges of the Republic of Uzbekistan. Supreme Council of Judges of the Republic of Uzbekistan-T.: "Adolat", 2018.-112 p.

2. Radjabova. M.A. "Honesty of a judge is the basis of the triumph of justice in society" Criteria of justice Scientific and practical, legal journal. No.10. 2020, 26$28 \mathrm{p}$.

3. I.I. Bekmirzaev., N.M. Mirzaev. "Judicial Ethics in Islam". Tutorial. Published by Qaqnus Media. T. 2019 